\title{
Absolute Isotopic Abundance of Terrestrial Silver
}

\author{
William R. Shields, Ernest L. Garner, and Vernon H. Dibeler
}

(September 28, 1961)

\begin{abstract}
Isotopic abundance ratios are reported for a commercial silver nitrate, 13 samples of native silver, and 11 silver minerals of various compositions and from widely distributed deposits. Collateral measurements of known mixtures of nearly pure silver isotopes permit the determination of absolute abundance ratios. Native silver from Cobalt, Ontario, previously reported as exhibiting statistically significant variation, is re-examined. Additional measurements are reported for samples from the same nugget and from the same region. Except for the original observation, no significant variation from normal abundance is observed for any of the samples. The $\mathrm{Ag}^{107} / \mathrm{Ag}^{109}$ ratio obtained from pooling the data is 1.07597 with a 95 percent confidence limit of \pm 0.00055 for the effect of random errors and a total uncertainty of \pm 0.00135 when an allowance for the possible effects of known sources of systematic error is included.
\end{abstract}

\section{Introduction}

In a recent determination of the absolute isotopic abundance ratio of silver, Shields, Craig, and Dibeler $[1]^{1}$ carefully measured the $\mathrm{Ag}^{107} / \mathrm{Ag}^{109}$ ratio for several samples of native silver. They reported a statistically significant variation in the ratio for one sample from Cobalt, Ontario compared with six samples from other localities. Previous investigations of a possible variation in the isotope ratio of natural silver have been limited to processed bulk silver [2] or to a very few mineral samples. Hess, Marshall, and Urey [3] have reported no variation among four samples of terrestrial silver and one sample of Toluca Troilite. However, their limit for detection of variation was about 2 percent of the isotope ratio. Murthy [4] has recently made a more precise comparison of Toluca Troilite with commercial silver nitrate and finds about a 2 percent enrichment of $\mathrm{Ag}^{107}$ in the troilite. As the apparent variation reported for Cobalt silver is only a fraction of this amount, a careful re-examination has been made of native silver samples, including some from the Cobalt area. In addition, measurements have been made on a number of silver minerals from widely scattered deposits to provide a broader basis for establishing a limit to the natural variation in the isotope abundance of terrestrial silver.

\section{Experimental Procedure}

The mass spectrometer used in this research is a 12 -in. radius-of-curvature, $68^{\circ}$ deflection with $60^{\circ}$ magnet, single focusing, surface emission instrument. The triple filament source uses all rhenium ribbons $1 \times 30$ mils. The usual techniques were employed for preparing sample filaments for surface emission using of the order of $100 \mu \mathrm{g}$ of sample. No extraneous material was required or used to produce satisfactory emission characteristics for $\mathrm{Ag}^{+}$ions.

*This work was supported in part by the U.S. Atomic Energy Commission.

${ }^{1}$ Figures in brackets indicate the literature references at the end of this paper.
Ion currents were measured with a vibrating reed electrometer. Isotope ratios were measured both by comparison of the $\mathrm{Ag}^{107}$ and $\mathrm{Ag}^{109}$ ion currents collected alternately on the Faraday collector and by a ratio-record method using an expanded scale recorder. $^{2}$

All ratio measurements of the calibration mixtures and the commercial and natural samples were obtained under standardized conditions of essentially constant sample size and nominal ion currents of $1 \times 10^{-11}$ amp. The latter was controlled by adjustment of the filament temperatures. Observations were made on a strict time schedule as illustrated in figure 1 . The plot represents a typical set of uncorrected data for eight analyses of a commercial silver nitrate. Each analysis consists of three ratios observed at 10 -min intervals starting $20 \mathrm{~min}$ after filaments are turned on. Curve $A$ represents the set of

2 This circuit and other details of construction of the instrument used in this work will be published elsewhere.

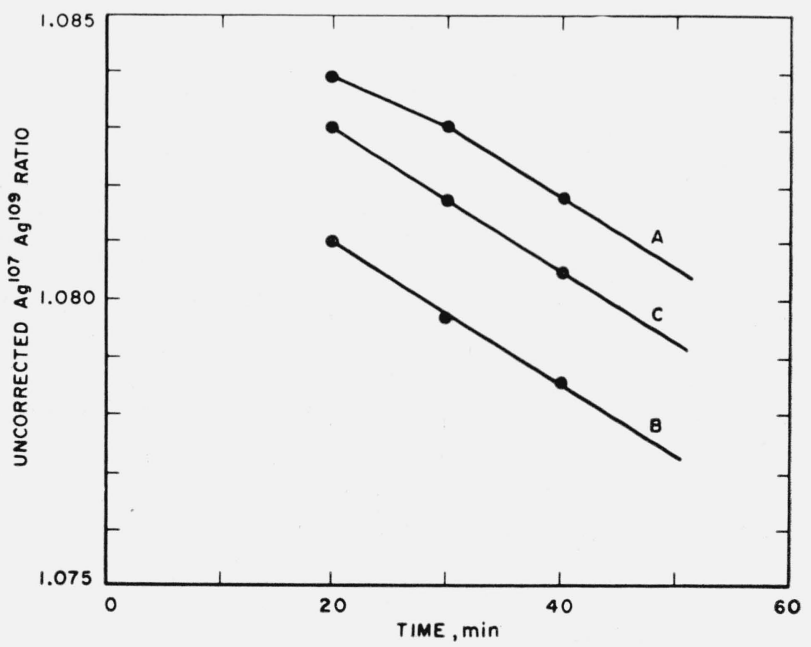

FIGURE 1. Typical uncorrected ratio measurements for commercial silver nitrate as a function of time.

Of eight analyses, curves A and B represent the highest and lowest observed ratios, respectively. Curve $C$ represents the average of all eight analyses. 
data with the highest observed $\mathrm{Ag}^{107} / \mathrm{Ag}^{109}$ ratios, curve B represents the lowest ratios, and curve C represents the average ratios of all eight analyses. A variation in abundance ratio with time is observed. Mass spectra were obtained by varying the magnetic field by means of a reversible motor-driven control Helipot.

Except as otherwise indicated, the natural silver samples were obtained from collections of the U.S. National Museum, Smithsonian Institution through the courtesy of Paul E. Desautels and selected by Thomas W. Stern of the U.S. Geological Survey. Details of the preparation and measurement of the native silver samples and of the calibration mixtures of nearly pure isotopes are given by Shields, et al., [1]. The mineral samples were prepared for analysis by Rolf $\mathrm{A}$. Paulson using well-known procedures and taking care to prevent contamination or separation of isotopes during the solution process. No effort was made to purify mineral samples to better than 80 percent silver. Native silver samples were not purified.

\section{Results and Discussion}

Tables 1, 2, and 3 summarize the data for the various silver samples examined in this study. Column 1 gives the U.S. National Museum catalog number, when applicable. Columns 2 and 3 identify the ore and locality, respectively. Column 4 lists the absolute $\mathrm{Ag}^{107} / \mathrm{Ag}^{109}$ ratios and column 5 gives the 95 percent confidence limit for the effect of random errors in the analytical procedure. The data for silver nitrate reference obtained with each group of samples is given in each table.

The native silver samples of table 1 were analyzed by mass scanning. Each sample was analyzed four times with eighteen ratio pairs taken within each analysis. The mineral silver samples in table 3 were analyzed with a ratio recording measuring circuit. Each sample was analyzed twice with three ratios observed at $10 \mathrm{~min}$ intervals for each sample. Cobalt samples (1), (2), and (3) of table 2 were analyzed with the ratio recording measuring circuit and all other samples were analyzed by mass scanning.

The high value for the cobalt (1) sample (table 2) must remain unreconciled. The nugget from which this sample was cut is part of a private collection donated to the National Museum and some uncertainty must be attributed to its origin. However, the isotope ratio of the two samples subsequently obtained from the same nugget are in accord with all other silver samples. Thus, the average of these three samples (1.0764) is taken as the value representative of the silver from this area.

It is apparent that the observed differences among all samples are less than expected on the basis of random errors associated with the measurements. Therefore, all samples must be regarded as having the same isotope abundance ratio within these limits ( 0.2 percent of the ratio). Nevertheless, it is interesting to note that in general the isotope abundance
Table 1. Native Silver Samples

\begin{tabular}{|c|c|c|c|c|}
\hline $\begin{array}{l}\text { U.S.N.M. } \\
\text { Catalog No. }\end{array}$ & Composition & Locality & $\mathrm{Ag}^{107 / \mathrm{Ag}^{109}}$ & $\begin{array}{c}\text { Analytical } \\
\text { error a }\end{array}$ \\
\hline & Silver Nitrate_.. & Commercial materi- & 1.0755 & $0.0 n 13$ \\
\hline $65154 \ldots$ & Native Silver... & Silver King Mine, & 1.0734 & \\
\hline 5791 & Native Silver.-. & $\begin{array}{l}\text { PinalCo., Arizona } \\
\text { Ontonagon, Lake } \\
\text { Superior District, } \\
\text { Mich. }\end{array}$ & 1.0766 & \\
\hline $81784 \ldots \ldots$ & Native Silver & GagnonMine, Butte & 1. 0744 & .0025 \\
\hline 112858 & Native Silver... & El Mochito Mine, & 1.0746 & \\
\hline C-162 & Native Silver & Chihuahua, Mexico & 1. 0755 & \\
\hline 62845 & Native Silver.... & Kongsberg, Norway & 1. 0744 & \\
\hline
\end{tabular}

a This uncertainty is the 95 percent confidence limit for the effect of random errors in the analytical procedure.

Table 2. Cobalt Silver Samples

\begin{tabular}{|c|c|c|c|c|}
\hline $\begin{array}{l}\text { U.S.N.M. } \\
\text { Catalog No. }\end{array}$ & Composition & Locality & Ag107/Ag109 & $\begin{array}{c}\text { Analytical } \\
\text { error }{ }^{\circ}\end{array}$ \\
\hline $\begin{array}{l}\mathrm{C}-140(1)^{\mathrm{a}} \ldots \\
\mathrm{C}-140(2)^{\mathrm{a}} \ldots \\
\mathrm{C}-140(3)^{\mathrm{a}} \ldots\end{array}$ & 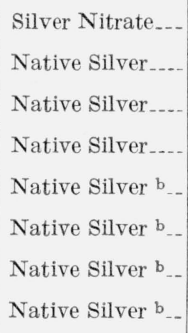 & $\begin{array}{l}\text { Commercial materi- } \\
\text { al lot } 90138 \\
\text { Cobalt, Ontario, } \\
\text { Canada } \\
\text { Cobalt, Ontario, } \\
\text { Canada } \\
\text { Cobalt, Ontario, } \\
\text { Canada } \\
\text { Silver Miller Mine, } \\
\text { Cobalt Camp } \\
\text { Nova Scotia Mine, } \\
\text { Cobalt Camp } \\
\text { Silver Banner Mine, } \\
\text { Cobalt Camp } \\
\text { Great Bear Lake, }\end{array}$ & $\begin{array}{l}1.0763 \\
1.0783_{-}(1) \\
1.0758 \text { (2) } \\
1.0753 \text { (3) } \\
1.0746 \\
1.0743 \\
1.0736 \\
1.0745\end{array}$ & 0.0009 \\
\hline
\end{tabular}

- Three chips cut from different sides of the same nugget.

b Kindly supplied by the Canadian Geological survey through Dr. Frank E. Senftle, U.S.G.S.

o See footnote to table 1.

TABLE 3. Mineral Silver Samples

\begin{tabular}{|c|c|c|c|c|c|}
\hline $\begin{array}{l}\text { U.S.N.M. } \\
\text { Catalog No. }\end{array}$ & Composition & \multicolumn{2}{|c|}{ Locality } & Ag107/Ag190 & $\begin{array}{c}\text { Analytical } \\
\text { error a }\end{array}$ \\
\hline $\begin{array}{l}80263 \\
\text { R-1215 } \\
\text { R-1226. } \\
\text { C-816 } \\
96041 \\
\text { C-330 } \\
62877 \\
\text { R-1144 } \\
\text { C-5638 } \\
9525 \\
92933\end{array}$ & $\begin{array}{l}\text { Silver Nitrate } \\
\text { Bromyrite } \\
\text { Cerargyrite } \\
\text { Embolite } \\
\text { Freibergite } \\
\text { Naumannite } \\
\text { Hessite } \\
\text { Argentite } \\
\text { Polybasite } \\
\text { Stephanite } \\
\text { Pyrargyrite } \\
\text { Proustite }\end{array}$ & $\begin{array}{l}\text { Comme } \\
\text { rial, lo } \\
\text { Australi } \\
\text { Arizona } \\
\text { Australi } \\
\text { Bolivia } \\
\text { Idaho } \\
\text { Transyl } \\
\text { German } \\
\text { Mexico } \\
\text { German } \\
\text { German } \\
\text { Chile }\end{array}$ & $\begin{array}{l}\text { ial mate- } \\
90138 \\
\text { ania }\end{array}$ & $\begin{array}{l}1.0758 \\
1.0752 \\
1.0750 \\
1.0756 \\
1.0754 \\
1.0751 \\
1.0754 \\
1.0752 \\
1.0743 \\
1.0757 \\
1.0750 \\
1.0746\end{array}$ & .00155 \\
\hline \multirow{3}{*}{92933} & \multicolumn{3}{|c|}{ Silver nitrate summary } & \multirow{2}{*}{$\begin{array}{l}\text { Analytical } \\
\text { error a }\end{array}$} & \multirow{2}{*}{$\begin{array}{l}\text { Total un- } \\
\text { certainty b }\end{array}$} \\
\hline & \multirow{2}{*}{\multicolumn{2}{|c|}{$\begin{array}{l}\text { Shields, Craig, and Di- } \\
\text { beler }(1960) \\
\text { Pooled data-present work }\end{array}$}} & $\operatorname{Ag}^{107} / \operatorname{Ag}^{109}$ & & \\
\hline & & & $\begin{array}{l}\text { 1. } 07547 \\
\text { 1. } 07597\end{array}$ & $\begin{array}{l} \pm 0.00126 \\
\pm 0.00055\end{array}$ & $\begin{array}{l} \pm 0.00206 \\
\pm 0.00135\end{array}$ \\
\hline
\end{tabular}

a See footnote to table 1.

b Analytical error plus an allowance for possible effect due to known sources of systematic error.

ratios for natural silver samples are lower than that of the commercial silver nitrate. This is presently attributed to the lower silver purity in the natural samples compared with the chemically pure silver nitrate from the commercial and calibration samples. 
It has been observed consistently that the $\mathrm{Ag}^{107} / \mathrm{Ag}^{109}$ ratio for a given sample regardless of origin was low if any difficulty was experienced in obtaining the standardized intensity level for the $\mathrm{Ag}^{+}$ion current or otherwise required higher-than-normal filament temperatures.

The proper means of obtaining the "best estimate" of the $\mathrm{Ag}^{107} / \mathrm{Ag}^{109}$ ratio is not obvious. However, the total number of measurements of the commercial silver nitrate, lot 90138, greatly exceeds all other samples. Furthermore, this material is isotopically indistinguishable from the other samples. If all the information observed to date for the commercial silver nitrate is pooled, the unbiased estimate of $\mathrm{Ag}^{107}$; $\mathrm{Ag}^{109}=1.07597$. The 95 percent confidence limit for the effect of random errors on this combined value is \pm 0.00055 . This limit of error plus a limit for possi- ble systematic error gives the overall limit for the $\mathrm{Ag} /{ }^{107} / \mathrm{Ag}^{109}$ ratio of \pm 0.00135 . The value for the ratio does not differ significantly from that previously reported by Shields et al., but can be stated with a smaller uncertainty.

\section{References}

[1] W. R. Shields, D. N. Craig, and V. H. Dibeler, J. Amer. Chem. Soc. 82, 5033-5036 (1960).

[2] E. A. C. Crouch, E. R. Preece, I. G. Swainbank, and A. H. Turnbull, Nature 184, No. 4683 (Suppl.), 358 (1959).

[3] D. C. Hess, R. R. Marshall, and H. C. Urey, Science, 126, 1291-1293 (1958).

[4] U. R. Murthy, Phys, Rev. Letters 5, No. 12, 539-541 (1960).

(Paper 66A1-135) 